\title{
Equitable Modification of Time Limitations Under Title VII
}

Title VII of the Civil Rights Act of $1964,{ }^{1}$ which prohibits discrimination in employment on the basis of race, color, religion, sex, or national origin, ${ }^{2}$ contains an elaborate series of procedures by which an aggrieved employee may seek relief. Each of these procedures is conditioned by a time limitation. To take advantage of Title VII's remedies, the complainant ${ }^{3}$ must file a charge with the Equal Employment Opportunity Commission ("EEOC") within 180 days of the discriminatory act, ${ }^{4}$ after which the Commission is empowered to investigate and, if it determines that a violation has occurred, to seek voluntary compliance. ${ }^{5}$ The EEOC may bring a civil action if its efforts to conciliate fail; ${ }^{b}$ if it declines to pursue the case within 180 days of the filing or if it dismisses the charge, it must notify the complainant, who then may file a civil action within 90 days of receiving the notice. ${ }^{7}$ Jurisdiction over such

142 U.S.C. $\$ \$ 2000$ e-2000e-17 (1976 \& Supp. II 1978) [hereinafter cited without crossreference as Title VII].

2 Title VII $\S 703,42$ U.S.C. $\S 2000 \mathrm{e}-2$ (1976).

3 The charge also may be filed by another on the complainant's behalf, or by a member of the EEOC. Id. \& 706(b), 42 U.S.C. \& 2000e-5(b) (1976).

4 Id. $\S 706(\mathrm{e}), 42$ U.S.C. $\S 2000 \mathrm{e}-5(\mathrm{e})$ (1976). As originally enacted, this time limitation was 90 days. 42 U.S.C. $\$ 2000$ e-5(d) (1970) (amended 1972). It was increased to 180 days by the Equal Employment Opportunity Act of 1972, Pub. L. No. 92-261, §4, 86 Stat. 105. The procedure is slightly difierent if the employee's state has a law prohibiting employment discrimination and an agency charged with enforcing it; in that case, the complainant must follow the state procedure before he may invoke EEOC procedures. Charges may not be filed with the EEOC until 60 days after proceedings have commenced before the state agency or until the state proceedings have been terminated, whichever is earlier. Title VII $\S 706$ (c), 42 U.S.C. $\$ 2000$ e-5(c) (1976). The other time limitations are adjusted accordingly to allow for this deferral period. Id. § 706(e), 42 U.S.C. $\$ 2000 \mathrm{e}-5(\mathrm{e})(1976)$.

S Id. § 706(b), 42 U.S.C. $₹ 2000 \mathrm{e}-5(\mathrm{~b})(1976)$.

- Id. § 706(f), 42 U.S.C. $\$ 2000 \mathrm{e}-5(\mathrm{f})$ (1976).

7 Id. The law as originally enacted provided the EEOC no enforcement powers other than conciliation. If the EEOC failed to secure voluntary compliance within 30 days of the filing of the charge (extendible to 60 days), it issued a "right-to-sue" letter to the complainant, who then had 30 days to file suit. Id. $\S 706(\mathrm{e}), 42$ U.S.C. $\$ 2000 \mathrm{e}-5(\mathrm{e})(1970)$ (amended 1972).

The original version of the Act did not prohibit discrimination by the federal government as an employer, id. § 701(b), 42 U.S.C. $\S 2000 \mathrm{e}$ (b) (1970), but the 1972 amendments added special liability and time limitation provisions to fill this gap. Equal Employment 
actions is vested in the federal district courts. ${ }^{8}$

The time limitations for asserting these remedies have sparked considerable controversy in the courts. ${ }^{9}$ Some have held that the time limits must be construed literally and strictly and therefore have concluded that they lack jurisdiction over late charges. ${ }^{10} \mathrm{~A}$ consequence of this "jurisdictional" characterization is that the requirement is absolute, cannot be waived, and may be raised either by a party or by the court on its own motion at any time. ${ }^{11}$ Other courts have held that the limitations are not jurisdictional, but operate like statutes of limitation. ${ }^{12}$ A consequence of this characterization is that noncompliance with the time limit sometimes may be excused, because statutes of limitation, although facially absolute, usually are subject to equitable modification in accordance with well-established principles. ${ }^{13}$ Such relief might take the form of delaying the time from which the statute runs (if, for example, the defendant fraudulently concealed the existence of the violation) ${ }^{14}$ or estopping the defendant from pleading the statute as a defense (if, for example, he agreed not to raise it, and the plaintiff relied on that promise). ${ }^{15}$ Still other courts have adopted an eclectic mix of these two characterizations, calling the limitations jurisdictional but allowing equitable tolling nevertheless. ${ }^{16}$ Another in-

Opportunity Act of 1972, Pub. L. No. 92-261, § 11, 86 Stat. 111 (codified at 42 U.S.C. $\S 2000 \mathrm{e}-16(1976))$.

Sitle VII § 706(f)(3), 42 U.S.C. § 2000e-5(f)(3) (1976).

- Most of the controversy has centered on the time limit for filing charges with the EEOC. At least one case has surmised that equitable tolling may be appropriate in the context of the initial filing requirement but not in the context of other time limitations. Cooper v. Bell, 628 F.2d 1208, 1213 n.9 (9th Cir. 1980). The rationale was that once a complainant has surmounted the hurdle of the initial filing, he is probably well-informed about his rights and obligations, so that any later delay would be less excusable. This argument goes only to the likelihood that equitable modification will be appropriate, however, and does not present a compelling reason for precluding such modification in all cases. This comment's conclusions therefore apply to all Title VII time limitations. Accordingly, the notes that follow do not specify which time limitation each cited case construed.

10 See text and notes at notes 19-22 infra.

1 FED. R. Crv. P. 12(h)(3).

12 See text and notes at notes 31-36 infra.

13 See Holmberg v. Armbrecht, 327 U.S. 392, 397 (1946) ("This equitable doctrine is read into every federal statute of limitation. If the Federal Farm Loan Act had an explicit statute of limitation ... the time would not have begun to run until after petitioners had discovered, or had failed in reasonable diligence to discover, the alleged deception ....").

14 E.g., Reeb v. Economic Opportunity Atlanta, Inc., 516 F.2d 924, 930 (5th Cir. 1975). This kind of relief involves an accrual rule.

${ }^{13}$ E.g., Leake v. University of Cincinnati, 605 F.2d 255, 259 (6th Cir. 1979). This kind of relief involves a tolling rule.

18 See text and note at note 30 infra. 
terpretation, rarely championed by the courts, is that the time limitations are "substantive statutes of limitation" that circumscribe the right and not merely the remedy and therefore cannot be modified. ${ }^{17}$

Most of the academic commentary on this question has examined the inconclusive language of the statute, its problematic legislative history, and conflicting policy arguments in an effort to prove positively that the time limitations are statutes of limitation and not absolute. ${ }^{18}$ There has been a shortage, however, of critical analysis of the opposing interpretations; accordingly, this comment examines the origins and bases of those readings of the statute. Finding that each is unsatisfactory, it concludes that equitable modification should be allowed under Title VII, as it is under similar statutes, in the absence of any evidence that Congress meant to preclude it.

\section{Time Limitations as a Condition of Subject Matter JURISDICTION}

In several early cases, federal appellate courts characterized Title VII time limitations as "jurisdictional prerequisites," although that description was either dictum or not critical to the outcome. ${ }^{19}$ The Supreme Court joined this chorus by repeating the

${ }_{17}$ Goodman v. City Prods. Corp., Ben Franklin Div., 425 F.2d 702, 704 (6th Cir. 1970). Cf. EEOC v. Louisville \& N.R.R., 505 F.2d 610, 613-14 (5th Cir. 1974) (mentioning this rule but holding it inapplicable). See part II-A infra.

18 E.g., Bukes, Administrative Prerequisites to Litigation Under Title VII of the Civil Rights Act of 1964-Recent Developments, 17 DuQ. L. REv. 633 (1978-79); Jackson \& Matheson, The Continuing Violation Theory and the Concept of Jurisdiction in Title VII Suits, 67 GEo. L.J. 811, 841-50 (1979); Note, Limitation Period for Filing a Charge with the Equal Employment Opportunity Commission Under Title VII of the Civil Rights Act of 1964, 56 B.U.L. Rev. 760 (1976) [hereinafter cited as Boston Note]; Comment, Jurisdictional Prerequisites to Private Actions Under Title VII of the Civil Rights Act of 1964, 41 Mo. L. REv. 215 (1976) [hereinafter cited as Missouri Comment]; Note, 58 N.C.L. Rzv. 395 (1980); 55 Notre Dame Law. 614 (1980); 55 Notre Dame Law. 396 (1980).

19 Macklin v. Spector Freight Syss., Inc., 478 F.2d 979, 986 (D.C. Cir. 1973) (timely filing is a jurisdictional prerequisite, but because plaintiff alleged a continuing violation the time limit had not run); Vigil v. AT\&T, 455 F.2d 1222, 1224 (10th Cir. 1972) (filing with EEOC during period when state agency had exclusive jurisdiction met jurisdictional requirement); Harris v. National Tea Co., 454 F.2d 307, 312 (7th Cir. 1971) (dismissal for lack of subject matter jurisdiction was proper when plaintiff did not file within the time limit and presented no good reason to toll the limit); Beverly v. Lone Star Lead Constr. Co., 437 F.2d 1136, 1139 (5th Cir. 1971) (although EEOC had found no reasonable cause to believe there was discrimination, complaint satisfied "minimal jurisdictional requirements"); Miller v. International Paper Co., 408 F.2d 283, 284-85 (5th Cir. 1969) (not every member of a class must meet the "jurisdictional prerequisite" of timely filing); Choate v. Caterpillar Tractor 
phrase several times in dictum. ${ }^{20}$ This apparent endorsement of the notion, although its implications had not been articulated, led some courts to conclude that the usual iron consequences of jurisdictional prerequisites must apply. ${ }^{21}$ Other courts repeated the "jurisdictional prerequisite" language even when noting that no circumstances could support equitable modification in the cases before them; they therefore left unclear whether the "jurisdictional" characterization was mere dictum. ${ }^{22}$

Co., 402 F.2d 357, 359 (7th Cir. 1968) (despite failure to file charges under oath, plaintiff met the "only ... jurisdictional prerequisites").

${ }^{20}$ United Air Lines, Inc. v. Evans, 431 U.S. 553, 557 n.9 (1977) (jurisdiction cannot be based on an act that occurred more than a year before the filing of charges); Electrical Workers Local 790 v. Robbins \& Myers, Inc., 429 U.S. 229, 240-44 (1976) (time limitation is a jurisdictional prerequisite, but when given the benefit of the extended period established by the 1972 amendments, plaintiff met that requirement); Alexander v. Gardner-Denver Co., 415 U.S. 36, 47 (1974) (prior unfavorable arbitration result does not preclude a Title VII suit, because plaintiff satisfied the jurisdictional prerequisites); McDonnell Douglas Corp. v. Green, 411 U.S. 792, 798 (1973) (EEOC's failure to find reasonable cause to believe there was discrimination did not preclude a Title VII suit, because plaintiff satisfied the jurisdictional prerequisites).

${ }^{21}$ Verzosa v. Merrill Lynch, Pierce, Fenner \& Smith, Inc., 589 F.2d 974, 977 (9th Cir. 1978) (per curiam) (court must raise jurisdictional issue despite parties' stipulation of timeliness because jurisdiction cannot be conferred by agreement, but defendant's stipulation to facts supporting plaintiff's claim of a continuing violation made the charge timely); In re Consolidated Pretrial Proceedings in the Airline Cases, 582 F.2d 1142, 1151-52 (7th Cir. 1978) (jurisdictional nature of requirement precludes finding that defendant waived the defense; moreover, defendant cannot be estopped from raising defense), cert. granted, $101 \mathrm{~S}$. Ct. 1511, cert. dismissed in part, 101 S. Ct. 2308, 2309 (1981); Cutliff v. Greyhound Lines, Inc., 558 F.2d 803, 806 (5th Cir. 1977) (proof of timeliness is part of plaintiff's burden); Hinton v. CPC Int'l, Inc., 520 F.2d 1312, 1315, 1316 (8th Cir. 1975) (although defendant promised not to raise time limitation as a defense, district court properly raised the jurisdictional issue on its own motion); Cleveland v. Douglas Aircraft Co., 509 F.2d 1027, 1029, 1030 (9th Cir. 1975) (court lacked jurisdiction even though plaintiff's untimeliness was EEOC's fault); Wetzel v. Liberty Mut. Ins. Co., 508 F.2d 239, 246 n.8 (3d Cir.) (court may consider issue on appeal even though it was not raised at trial), cert. denied, 421 U.S. 1011 (1975).

22 Movement for Opportunity \& Equality v. General Motors Corp., 622 F.2d 1235, 124041 (7th Cir. 1980); Nilsen v. City of Moss Point, 621 F.2d 117, 120, 121 (5th Cir. 1980); Hamilton v. General Motors Corp., 606 F.2d 576, 578-79 (5th Cir. 1979), cert. denied, 447 U.S. 907 (1980); Greene v. Carter Carburetor Co., 532 F.2d 125, 126, 127 (8th Cir. 1976); Terry v. Bridgeport Brass Co., 519 F.2d 806, 807-08 (7th Cir. 1975); East v. Romine, Inc., 518 F.2d 332, 337 (5th Cir. 1975); Wong v. Bon Marche, 508 F.2d 1249, 1250-51 (9th Cir. 1975) (per curiam).

Contrast cases in which the jurisdictional issue was reserved expressly because equitable modification would be unwarranted in any event: Villasenor v. Lockheed Aircraft Corp., 640 F.2d 207, 207 (9th Cir. 1981) (per curiam); Satz v. ITT Financial Corp., 619 F.2d 738, 745 n.11 (8th Cir. 1980); Larson v. American Wheel \& Brake, Inc., 610 F.2d 506, 508, 511 (8th Cir. 1979); Daughtry v. King's Dep't Stores, Inc., 608 F.2d 906, 909 (1st Cir. 1979) (per curiam); Stuppiello v. ITT Avionics Div., 575 F.2d 430, 432 n.4 (3d Cir. 1978); Smith v. American President Lines, Ltd., 571 F.2d 102, 109 (2d Cir. 1978). 
The difficulty with this extensive body of authority ${ }^{23}$ is that no court has ever expounded any reason for considering the requirements to be jurisdictional. ${ }^{24}$ Conditions that narrow the federal courts' jurisdiction to smaller confines than their full constitutional range, such as the amount in controversy requirement, ${ }^{25}$ simply affect the allocation of cases between state and federal courts. ${ }^{28} \mathrm{Un}$ like such jurisdictional conditions, the time limitations of Title VII define the merits of the claim and therefore serve a very different purpose. ${ }^{27}$ As the Supreme Court has noted, that purpose is the promotion of fairness to all parties through the prevention of stale claims $^{28}$ - a purpose generally served by statutes of limitation..$^{28}$

${ }^{23}$ In fact, the Supreme Court's precedents are not uniform. The Court has called the time limits statutes of limitation as often as it has called them a jurisdictional bar. See Delaware State College v. Ricks, 449 U.S. 250, 256, 266 (1980) (time limitation and section 1981 statute of limitation compared; dissent referred to it as statute of limitation); United Air Lines, Inc. v. McDonald, 432 U.S. 385, 392, 397-98 (1977) (majority and dissent both referred to it as statute of limitation); Occidental Life Ins. Co. v. EEOC, 432 U.S. 355, 37172 (1977) (time limitation called a statute of limitation); Electrical Workers Local $790 \mathrm{v}$. Robbins \& Myers, Inc., 429 U.S. 229, 243-44 (1976) (amendment increasing time limitation to 180 days held to revive claim barred under old limit on strength of authority relating to statutes of limitation).

${ }^{24}$ See Hart v. J.T. Baker Chem. Co., 598 F.2d 829, 832 (3d Cir. 1979) ("[T]he genesis of the term 'jurisdictional prerequisite' demonstrates that the term has crept into Title VII jurisprudence with no explication of its underlying logic and thus no real guidance in determining its applicability.").

${ }^{2 s} 28$ U.S.C. $\$ 1332$ (1976).

${ }^{28}$ C. Wright, Handbook of the Law of Federal Courts $\S \S 1,48$ (3d ed. 1976); M. Redish, Federal Jurisdiction: Tensions in the Allocation of Judicial Power 21-24 (1980).

${ }^{27}$ See McArthur v. Southern Airways, Inc., 569 F.2d 276, 279 (5th Cir. 1978) (Rubin, J., dissenting):

[A] claim that is not timely filed is subject to dismissal either on the ground that the plaintiff has not stated a claim for which relief could be granted, or, if the facts do not appear on the face of the pleadings, on motion for summary judgment. But these are dismissals because the claim has no merit, not because the court lacks subject matter jurisdiction.

A court is not deprived of subject matter jurisdiction when a claim before it is defective on the merits. See Bell v. Hood, 327 U.S. 678, 682 (1946).

${ }^{28}$ Occidental Life Ins. Co. v. EEOC, 432 U.S. 355, 371-72 (1977) (footnotes omitted): Congress did express concern for the need of time limitations in the fair operation of the Act, but that concern was directed entirely to the initial filing of a charge with the EEOC and prompt notification thereafter to the alleged violator. The bills passed in both the House and Senate contained short time periods within which charges were to be filed with the EEOC and notice given to the employer. And the debates and reports in both Houses made evident that the statute of limitations problem was perceived in terms of these provisions. ...

The fact that the only statute of limitations discussions in Congress were directed to the period preceding the filing of an initial charge is wholly consistent with the Act's overall enforcement structure.... 
The sheer bulk of the dicta declaring the time limits to be jurisdictional has caused courts uncomfortable with that interpretation to resort to curious evasions. In many cases they have retained the jurisdictional label but changed its meaning. For instance, one court held that "Title VII time limitations are jurisdictional in the sense that the phrase is used in relation to statutes of limitations and equitable principles should apply in circumstances which warrant their application."

Courts that reject the jurisdictional label outright, ${ }^{31}$ on the other hand, have taken the defensive, seeking to prove the obvious proposition that the time periods specified in the statute are "periods of limitation" by citation to unsurprising statements in the committee reports and congressional debates to that effect. ${ }^{32}$ They bolster this conclusion by noting the remedial nature of the statute and the fact that the charges must be filed by laymen, ${ }^{33}$ reasoning

29 See Johnson v. Railway Express Agency, Inc., 421 U.S. 454, 465-66 (1975) (a statute of limitation "reflects a value judgment concerning the point at which the interests in favor of protecting valid claims are outweighed by the interests in prohibiting the prosecution of stale ones"). In appropriate circumstances, equitable modification is allowed despite this legislative balance because the assumptions underlying the balance do not include misconduct on the defendant's part. Modifying the time limitation prevents such a defendant from "profiting from his own wrong." Glus v. Brooklyn E. Dist. Terminal, 359 U.S. 231, 232-35 (1959).

so Leake v. University of Cincinnati, 605 F.2d 255, 259 (6th Cir. 1979). See also Bethel v. Jefferson, 589 F.2d 631, 641-42 (D.C. Cir. 1978) (equitable modification is available because the time limitations are "not jurisdictional in the strict sense"); Bickham v. Miller, 584 F.2d 736, 738 (5th Cir. 1978) (per curiam) (even though "timely filing is jurisdictional, ... the commencement of the filing period [may be] delayed in certain instances until a complainant learns or could be reasonably expected to learn of the discriminatory act"); Reeb v. Economic Opportunity Atlanta, Inc., 516 F.2d 924, 928 (5th Cir. 1975) ("[T]he ninety day requirement is not 'jurisdictional' in the sense that compliance with it vel non determines the jurisdiction of the district court, without respect to any of the other circumstances in a particular case."). Compare similar interpretations of analogous requirements under the Age Discrimination in Employment Act of 1967 ("ADEA"), 29 U.S.C. $\$ \S 621-634$ (1976), as amended by Age Discrimination in Employment Act Amendments of 1978, Pub. L. No. 95-256, 92 Stat. 189: Marshall v. Sun Oil Co., 605 F.2d 1331, 1337 n.8 (5th Cir. 1979) (dictum that conciliation requirement is not jurisdictional, but even if it were, equitable relief would be possible); Gabriele v. Chrysler Corp., 573 F.2d 949, 954 n.15 (6th Cir. 1978) (timely filing requirement is jurisdictional, but equitable relief is possible), vacated and remanded on other grounds, 442 U.S. 908 (1979).

s1 E.g., Laffey v. Northwest Airlines, Inc., 567 F.2d 429, 475 (D.C. Cir. 1976), cert. denied, 434 U.S. 1086 (1977).

${ }^{32}$ S. Rep. No. 415, 92d Cong., 1st Sess. 36-37 (1971) (relating to the 1972 amendments); 110 Cong. Rec. 7212, 7213 (1964) (memorandum authored by Sens. Clark \& Case); id. at 7243 (remarks of Sen. Case); id. at 12723 (remarks of Sen. Humphrey).

33 Hart v. J.T. Baker Chem. Corp., 598 F.2d 829, 831, 832 (3d Cir. 1979); Laffey v. Northwest Airlines, Inc., 567 F.2d 429, 475 (D.C. Cir. 1976), cert. denied, 434 U.S. 1086 (1977); Egelston v. State Univ. College, 535 F.2d 752, 754 (2d Cir. 1976); Reeb v. Economic 
that if equitable modification is sometimes called for, the time limits must not be jurisdictional. Sometimes the courts note that the section of the statute that establishes federal jurisdiction over these cases is unqualified. ${ }^{34}$ Finally, they argue that the time limitations do not behave like jurisdictional requirements: for example, although every member in a typical class action must meet the usual amount in controversy requirement, ${ }^{35}$ not every Title VII class member needs to file a timely charge. ${ }^{36}$

If some of these arguments seem strained, it is only because the courts have been forced to disprove an unlikely proposition, for neither the statute itself nor anyone in Congress called the time limitations jurisdictional, and those limitations serve no jurisdictional purpose. Proponents of the jurisdictional interpretation should be the ones citing support for their reading. Instead, repetition of the dictum seems to have convinced them that the statute itself makes that reading obvious. ${ }^{37}$

That dictum appears to have arisen from a careless use of language. One of the early appellate cases calling the time limits a "jurisdictional prerequisite" used the term interchangeably with "condition precedent." In In addition, other courts have held that the requirement of filing suit with the EEOC to allow an opportunity for conciliation before resorting to the courts is an exhaustion-

Opportunity Atlanta, Inc., 516 F.2d 924, 928 (5th Cir. 1975).

34 Hart v. J.T. Baker Chem. Corp., 598 F.2d 829, 832 (3d Cir. 1979); McArthur v. Southern Airways, Inc., 569 F.2d 276, 279 (5th Cir. 1978) (Rubin, J., dissenting). See text and note at note 8 supra.

${ }^{35}$ Zahn v. International Paper Co., 414 U.S. 291, 301 (1973).

${ }^{36}$ Chappell v. Emco Mach. Works Co., 601 F.2d 1295, 1298 (5th Cir. 1979); McArthur v. Southern Airways, Inc., 569 F.2d 276, 280 (5th Cir. 1978) (Rubin, J., dissenting).

s7 See In re Consolidated Pretrial Proceedings in the Airline Cases, 582 F.2d 1142, 1151 (7th Cir. 1978), cert. granted, 101 S. Ct. 1511, cert. dismissed in part, 101 S. Ct. 2308, 2309 (1981); Genovese v. Shell Oil Co., 488 F.2d 84, 85 (5th Cir. 1973) (per curiam) ("There is no room here for liberal or strict statutory construction since it is clear from the language of [the statute that the time limit] for the filing of suit is mandatory and jurisdictional."). Compare academic commentary accepting the label even when questioning its consequences: Boston Note, supra note 18, at 765 \& n.40; Missouri Comment, supra note 18, at 216-17, 225-26, 235-36.

ss Beverly v. Lone Star Lead Constr. Co., 437 F.2d 1136, 1139 (5th Cir. 1971). Accord, Cutliff v. Greyhound Lines, Inc., 558 F.2d 803, 806 (5th Cir. 1977). See also Cooper v. Bell, 628 F.2d 1208, 1211 (9th Cir. 1980) ("invocation of administrative remedies [is] a condition precedent to litigation"); Greene v. Carter Carburetor Co., 532 F.2d 125, 126 (8th Cir. 1976) (timely filing is a prerequisite, but court did not call it a "jurisdictional" prerequisite); Olson v. Rembrandt Printing Co., 511 F.2d 1228, 1231 (8th Cir. 1975) (semble). Cf. Gabriele v. Chrysler Corp., 573 F.2d 949, 954 n.15 (6th Cir. 1978) (construing time limitations of ADEA and noting that some courts use the term "jurisdictional prerequisite" in the loose sense of "condition precedent"), vacated and remanded on other grounds, 442 U.S. 908 (1979). 
of-remedies requirement. ${ }^{39}$ Neither of these formulations requires that equitable modification principles be forbidden in the administrative stage of the proceedings; they serve only to route the complaint through that stage before reaching court. ${ }^{40}$ The time limitations therefore need not be absolute. More importantly, a federal district court is not deprived of subject matter jurisdiction even if, with the aid of appropriate equitable modification principles, a claim fails to meet an exhaustion requirement. ${ }^{41}$ It is erroneous, therefore, to call such a prerequisite "jurisdictional."

The use of that label may have received some encouragement from analogies to the treatment of time limitations on other federally-created rights of action, such as the one contained in the Federal Tort Claims Act. ${ }^{42}$ Under such statutes, which create rights of action against the government, failure strictly to meet time limitations has been said to deprive the court of jurisdiction. ${ }^{43}$ The rationale for this rule is that "[c]onsent alone gives jurisdiction to adjudge against a sovereign. Absent that consent, the attempted exercise of judicial power is void."44 Whether or not the limitation of consent to be sued is properly viewed as a jurisdictional bar, ${ }^{45}$

s9 Cooper v. Bell, 628 F.2d 1208, 1213 (9th Cir. 1980); Bethel v. Jefferson, 589 F.2d 631, 641 (D.C. Cir. 1978); Swain v. Hoffman, 547 F.2d 921, 923 (5th Cir. 1977); East v. Romine, Inc., 518 F.2d 332, 336 (5th Cir. 1975).

to Some courts have recognized that such routing devices do not affect subject matter jurisdiction. See Boudreaux v. Baton Rouge Marine Contracting Co., 437 F.2d 1011, 1014 n.6 (5th Cir. 1971). Cf. Gabriele v. Chrysler Corp., 573 F.2d 949, 954 n.15 (6th Cir. 1978) (noting in the context of the ADEA that some cases "use the term 'jurisdictional' in the loose sense that [the time limits] are a condition precedent to suit in federal court and not in the strict sense that non-compliance deprives the district court of power to hear the case"), vacated and remanded on other grounds, 442 U.S. 908 (1979).

1 When the remedy to be exhausted is a state proceeding, a federal court dismisses premature suits "[a]s a matter of comity and equitable discretion . . . rather than as a limitation on jurisdiction." C. WRIGHT, supra note $26, \S 49$. Similarly, jurisdiction is not destroyed when the plaintiff has failed to exhaust federal administrative remedies. Briscoe v. Bell, 432 U.S. 404, $413 \mathrm{n} .13$ (1977) (distinguishing exhaustion requirements from preclusion of judicial review).

1228 U.S.C. § 2401 (1976 \& Supp. III 1979).

13 See Jankwich, Problems Under the Federal Tort Claims Act, 9 F.R.D. 143, 151 (1949), and cases cited therein. The same issue has arisen in the context of saving statutes, which serve a purpose similar to equitable modification. See W. Ferguson, The Statutes of Limitation Saving Statutes 224-27 (1978).

4t United States v. United States Fidelity \& Guar. Co., 309 U.S. 506, 514 (1940).

is It is probably more proper to construe the expiration of the time limitation in such a case as destroying the merits of the claim. See United States v. Kubrick, 444 U.S. 111, 11718 (1979) ("[T] [he [Federal Tort Claims] Act waives the immunity of the United States and . . . in construing the statute of limitations, which is a condition of that waiver, we should not take it upon ourselves to extend the waiver beyond that which Congress intended.") (emphasis added). The statute of limitation still may be absolute, however. See part II-B 
however, the analogy to Title VII fails insofar as Title VII creates a right of action against private parties.

Other statutes provide more useful analogies in construing Title VII. The Age Discrimination in Employment Act of 1967 ("ADEA"), ${ }^{46}$ although not analogous to Title VII in every respect, ${ }^{47}$ shares with it a common time limitation scheme. ${ }^{48}$ The courts therefore have used Title VII and ADEA precedents interchangeably. ${ }^{49}$ Most of the cases that have construed the time limitations under ADEA have concluded that they are not jurisdictional, but rather statutes of limitation subject to equitable modification. ${ }^{50}$

infra.

1829 U.S.C. $\$ \S 621-634$ (1976), as amended by Age Discrimination in Employment Act Amendments of 1978, Pub. L. No. 95-256, 92 Stat. 189.

47 Lorillard v. Pons, 434 U.S. 575, 583-85 (1978).

48 Oscar Mayer \& Co. v. Evans, 441 U.S. 750, 756 (1979) (specifically concerning time limitations when resort to state agency is required, but with broader reasoning).

10 See Coke v. General Adjustment Bureau, Inc., 640 F.2d 584, 587 (5th Cir. 1981) (en banc); Ewald v. Great Atl. \& Pac. Tea Co., 620 F.2d 1183, 1188 (6th Cir.), vacated and remanded on other grounds, 449 U.S. 914 (1980) (for reconsideration in light of a Title VII case, in fact); Dartt v. Shell Oil Co., 539 F.2d 1256, 1259-60 (10th Cir. 1976), aff'd per curiam by an equally divided court, 434 U.S. 99 (1977).

${ }^{80}$ Smallwood v. United Air Lines, Inc., No. 80-1111, slip op. at 14-15 (4th Cir. Sept. 17, 1981); Coke v. General Adjustment Bureau, Inc., 640 F.2d 584, 589 (5th Cir. 1981) (en banc); Wright v. Tennessee, 628 F.2d 949, 953 (6th Cir. 1980) (en banc); Ewald v. Great Atl. \& Pac. Tea Co., 620 F.2d 1183, 1187-88 (6th Cir.), vacated and remanded on other grounds, 449 U.S. 914 (1980); Marshall v. Sun Oil Co., 605 F.2d 1331, 1337 n.8 (5th Cir. 1979) (construing a conciliation rather than a timely filing requirement, but discussing both); Kephart v. Institute of Gas Technology, 581 F.2d 1287, 1288-89 (7th Cir. 1978); Reich v. Dow Badische Co., 575 F.2d 363, 370 (2d Cir.) (no equitable modification called for in this case, however), cert. denied, 439 U.S. 1006 (1978); Gabriele v. Chrysler Corp., 573 F.2d 949, 954 n.15 (6th Cir. 1978) (jurisdictional only in a loose sense), vacated and remanded on other grounds, 442 U.S. 908 (1979); Bonham v. Dresser Indus., Inc., 569 F.2d 187, 192-93 (3d Cir. 1977), cert. denied, 439 U.S. 821 (1978); Dartt v. Shell Oil Co., 539 F.2d 1256, 1259 (10th Cir. 1976), aff'd per curiam by an equally divided court, 434 U.S. 99 (1977). See also Comment, Procedural Prerequisites to Private Suit Under the Age Discrimination in Employment Act, 44 U. ChI. L. Rev. 457 (1977).

When Title VII was amended in 1972 and the 90-day limit for filing charges with the EEOC was increased to 180 days, Equal Employment Opportunity Act of 1972, Pub. L. No. 92-261, § 4, 86 Stat. 105 (codified at 42 U.S.C. § 2000e-5(e) (1976)), Congress did not make clear whether equitable modification should be allowed, although some evidence points in that direction. See 118 CoNG. REc. 4941 (1972) (section-by-section analysis placed in the record by Sen. Williams of New Jersey):

In establishing the new time period for the filing of charges, it is not intended that existing law, which has shown an inclination to interpret this type of time limitation to give the aggrieved person the maximum benefit of the law, should be in any way circumscribed. Existing case law which has determined that certain types of violations are continuing in nature, thereby measuring the running of the required time period from the last occurrence of the discrimination and not from the first occurrence is continued, and other interpretations of the courts maximizing the coverage of the law are not 
Similarly, the time limitation in section 10(b) of the Labor Management Relations Act ("LMRA")," a statute often used as a model in explicating Title VII's procedural scheme, ${ }^{52}$ has been held repeatedly to be a statute of limitation rather than a condition of jurisdiction. ${ }^{63}$

\section{Time Limitations as a Condition of the Right Rather THAN THE REMEDY}

Another analysis of Title VII's time limitations, distinct from the jurisdictional interpretation, occasionally has been used by the courts to reach a similar result." This analysis holds that the limi-

affected. It is intended by expanding the time period for filing charges in this subsection that aggrieved individuals, who frequently are untrained laymen who are not always aware of the discrimination which is practiced against them, should be given a greater opportunity to prepare their charges and file their complaints, and that existent but undiscovered acts of discrimination should not escape the effect of the law through a procedural oversight:

See also 118 Cong. Rec. 7167 (1972) (remarks of Sen. Williams).

When the ADEA was amended in 1978, by contrast, Congress clearly indicated that the time limits should not be absolute, even though it did not alter the time limit originally enacted. See H.R. Conf. REP. No. 950, 95th Cong., 2d Sess. 12 (1978), reprinted in [1978] U.S. CoDe Cong. \& AD. NEws 528, 534 ("The conferees agree that the 'charge' requirement is not a jurisdictional prerequisite to maintaining an action under the ADEA and that therefore equitable modification for failing to file within the time period will be available to plaintiffs under this Act [citing cases]."); S. REP. No. 493, 95th Cong., 2d Sess. 12 (1978), reprinted in [1978] U.S. Code CoNG. \& AD. NEwS 504, 515. Although this later explication of earlier legislative intent cannot be treated as dispositive, Oscar Mayer \& Co. v. Evans, 441 U.S. 750, 758 (1979), it is suggestive of what Congress may have meant by endorsing cases that give plaintiffs "the maximum benefit of the law" under Title VII.

s2 29 U.S.C. $\$ 160(b)$ (1976).

${ }^{32}$ See Mohasco Corp. v. Silver, 447 U.S. 807, 818 n.21 (1980); Franks v. Bowman Transp. Co., 424 U.S. 747, 768-70 (1976); Albemarle Paper Co. v. Moody, 422 U.S. 405, 419 \& n.11 (1975); 110 CoNG. REc. 6549 (1964) (remarks of Sen. Humphrey); id. at 7214 (interpretive memorandum authored by Sens. Clark \& Case). More specifically, the 180-day time limitation of the LMRA was the model for the extended period under Title VII. HousE Comm. on Educ. \& Labor, Equal Employment Opportunities Enforcement Act of 1971, H.R. Rep. No. 238, 92d Cong., 1st Sess. 65 (1971) (noted in minority section of the report, but not representing a point of disagreement); Senate Comm. on Labor \& Pub. Welfare, Equal. Employment Opportunities Act of 1971, S. Rep. No. 415, 92d Cong., 1st Sess. 37 (1971); 118 Cong. REc. 4941 (1972) (section-by-section analysis authored by Sen. Williams of New Jersey).

ss NLRB v. Laborers Int'l Union Local 264, 529 F.2d 778, 785 (8th Cir. 1976); Shumate v. NLRB, 452 F.2d 717, 721 (4th Cir. 1971); A.H. Belo Corp. v. NLRB, 411 F.2d 959, 966-67 (5th Cir. 1969), cert. denied, 396 U.S. 1007 (1970); NLRB v. A.E. Nettleton Co., 241 F.2d 130, 133 (2d Cir. 1967); NLRB v. Itasca Cotton Mfg. Co., 179 F.2d 504, 506-07 (5th Cir. 1950); Chicago Roll Forming Corp., 167 N.L.R.B. 961, 971 (1967), enforced, 418 F.2d 346 (7th Cir. 1969).

s See Coles v. Penny, 531 F.2d 609, 613 \& n.12 (D.C. Cir. 1976); Goodman v. City Prods. Corp., Ben Franklin Div., 425 F.2d 702, 703-04 (6th Cir. 1970). 
tation period defines the right, rather than the remedy, ${ }^{55}$ so that when the period has passed, the right is extinguished and cannot be revived.

Two Supreme Court cases have lent support to this view. In United Air Lines, Inc. v. Evans, ${ }^{56}$ the Court stated that "[a] discriminatory act which is not made the basis for a timely charge is the legal equivalent of a discriminatory act which occurred before the statute was passed. . . . [I]t is merely an unfortunate event in history which has no present legal consequences." 57 In Electrical Workers Local 790 v. Robbins \& Myers, Inc., ${ }^{68}$ the Court noted that Congress's establishment of a limitation period precludes the courts from interposing an independent judgment of what constitutes a proper limit..59

There are two avenues by which one might reach the conclusion that a time limit circumscribes an underlying right. Neither of these explanations, however, satisfactorily justifies the treatment of Title VII limitations as absolute.

\section{A. Substantive Statutes of Limitation}

The first line of analysis is grounded on an old theory that some statutes of limitation merely are procedural and therefore can be modified as equity dictates, but that others, labeled substantive, are an integral part of the right itself and therefore are inflexible. The original purpose of the "substantive" label, how-

ss Ordinary statutes of limitation do not obliterate the underlying right, but only abate the remedy, Davis v. Mills, 194 U.S. 451, 454 (1904), which may be revived in appropriate situations, either by a saving statute, see generally W. FERGUSON, supra note 43, or by equitable modification, see American Pipe \& Constr. Co. v. Utah, 414 U.S. 538, 558-59 (1974).

Bs 431 U.S. 553 (1977).

87 Id. at 558.

s8 429 U.S. 229 (1976).

bo Id. at 240. Cf. Mohasco Corp. v. Silver, 447 U.S. 807, 825-26 (1980):

[I]n a statutory scheme in which Congress carefully prescribed a series of deadlines measured by numbers of days-rather than months or years-we may not simply interject an additional 60-day period into the procedural scheme. We must respect the compromise embodied in the words chosen by Congress. It is not our place simply to alter the balance struck by Congress in procedural statutes by favoring one side or the other in matters of statutory construction.

It should be noted, however, that in Mohasco the plaintiff was arguing for a generalized extension, rather than one fashioned by equitable principles to fit particular circumstances.

It also should be noted that in Robbins \& Myers, the Court permitted a claim against which the old 90-day limitation had run to be revived by the later extension of that limitation. 429 U.S. at 243-44. If the expiration of the time limit really had extinguished the underlying claim, such a revival would not have been possible. 
ever, does not require inflexibility, as the Supreme Court has acknowledged. ${ }^{60}$

The theory arose as a conflict of laws principle. The usual common law conflicts rule held that when a right created by one state was sued upon in another, the statute of limitation of the forum state controlled. ${ }^{\text {i1 }}$ The rationale for this rule was that statutes of limitation are matters of procedure, and the forum's procedure is always used. ${ }^{62}$ In some situations, however, reliance on the statute of limitation of the state that created the right was perceived to be more appropriate. ${ }^{6 s}$ This occurred whenever the limitation was integrally attached to the right. ${ }^{64}$ Such limitations naturally came to be called "substantive" to distinguish them from ordinary "procedural" statutes of limitation.

The purpose of the distinction was merely to decide which state's limitation (and, presumably, rules of equitable modification) applied. ${ }^{65} \mathrm{~A}$ consequence of the "substantive" label, however, was that some courts held such limitations to be absolute and inflexible. ${ }^{68}$ This conclusion was fueled by an early Supreme Court description of such a statute:

The time within which the suit must be brought operates as a limitation of the liability itself as created, and not of the

so See text and notes at notes 68-69 infra.

-1 See A. de Cervera, The Statute of Limitations in American Conflicts of Laws 1 (1966).

2 Id. at 3-4.

6s This perception first arose when the forum state's period of limitation was longer than the one of the source of the right, and courts wished to choose the shorter. Id. at 21-22.

ot See Davis v. Mills, 194 U.S. 451, 454 (1904). Various tests for determining the existence of such integration have been employed. These include a "specificity" test (the limitation is not a generalized statute of limitation, but tailored for a specific right), a "built-in" test (the limitation is contained in the statute creating the right), an "attributes" test (the limitation has attributes the forum state considers to be substantive), and a "foreign courts" test (the limitation is considered substantive by courts of its home state). RESTATEMENT (SECOND) OF CoNfLICT of LAWS $§ 143$, Comment c \& Reporter's Note (1971). It frequently is said that newly-created rights not based in the common law are governed by this principle. A. DE Cervera, supra note 61, at 22.

os See A. DE Cervera, supra note 61, at 31.

Be This conclusion never was endorsed universally. See cases collected in Annot., 15 A.L.R.2d 500 (1951), and the analysis of the problem in Osbourne v. United States, 164 F.2d 767, 769 (2d Cir. 1947):

Whatever the reasons for describing this type of statute of limitations as substantive rather than procedural-and we suspect the chief reason was to make the period of limitation named in the statute, rather than the forum, control in cases brought in state courts-we think we do the distinction no violence by holding that either type of statute will toll [in appropriate circumstances].

See also Scarborough v. Atlantic Coast Line R.R., 178 F.2d 253, 258-59 (4th Cir. 1949). 
remedy alone. It is a condition attached to the right to sue at all. . . . The liability and the remedy are created by the same statutes, and the limitations of the remedy are, therefore, to be treated as limitations of the right. ${ }^{.7}$

Reliance on this statement as an argument for inflexibility has been misplaced, however, through oversight of the Court's reservation in the very next sentence of the possibility for equitable modification. ${ }^{68}$ In fact, the Supreme Court has held since that substantive statutes of limitation are susceptible of equitable modification. $^{6 \theta}$

\section{B. Unambiguous Statutes}

A statute of limitation also may create an absolute bar by containing a clear expression of legislative intent. Some statutes unambiguously state that suits may be maintained within a specified time "and not after," or that suits not brought within a specified time are "forever barred," or that "in no event shall [suit] be brought" after a specified time. ${ }^{72}$ Such statutes usually are con-

67 The Harrisburg, 119 U.S. 199, 214 (1886).

${ }^{68}$ Id. ("No question arises in this case as to the power of a court . . . to allow an equitable excuse for delay in suing, because no excuse of any kind has been shown."). In American Pipe \& Constr. Co. v. Utah, 414 U.S. 538, 557 (1974), the Supreme Court specifically noted that "The Harrisburg did not purport to define or restrict federal judicial power to delineate circumstances where the applicable statute of limitations would be tolled." The Court went on to hold that " $t$ t]he proper test is not whether a time limitation is 'substantive' or 'procedural,' but whether tolling the limitation in a given context is consonant with the legislative scheme." Id. at 557-58 (footnote omitted).

${ }_{69}^{6}$ Burnett v. New York Cent. R.R., 380 U.S. 424, 427 n.2 (1965):

The distinction between substantive and procedural statutes of limitations appears to have arisen in cases involving conflicts of laws. . . . While the embodiment of a limitation provision in the statute creating the right which it modifies might conceivably indicate a legislative intent that the right and limitation be applied together when the right is sued upon in a foreign forum, the fact that the right and limitation are written into the same statute does not indicate a legislative intent as to whether or when the statute of limitations should be tolled. Thus the "substantive"-"procedural" distinction would seem to be of little help in deciding questions of extending the limitation period.

See also American Pipe \& Constr. Co. v. Utah, 414 U.S. 538, 557-58 (1974); Glus v. Brooklyn E. Dist. Terminal, 359 U.S. 231, 232-35 (1959). Leake v. University of Cincinnati, 605 F.2d 255,259 (6th Cir. 1979), applies this reasoning to Title VII. See generally Note, 32 RuTGERS L. REv. 95 (1979).

${ }^{70}$ E.g., Interstate Commerce Act, 49 U.S.C. $\S 16(3)$ (a) (1976) (superseded by 49 U.S.C. $\S 11706$ (Supp. II 1979)).

71 E.g., Federal Tort Claims Act, 28 U.S.C. $\$ 2401$ (b) (1976).

72 E.g., Securities Act of 1933, 15 U.S.C. $\$ 77 \mathrm{~m}$ (1976); Interstate Land Sales Full Disclosure Act, 15 U.S.C. $\S 1711$ (1976) (superseded by 15 U.S.C. $\S 1711$ (Supp. II 1979)). 
strued as precluding equitable modification. ${ }^{73}$

This principle has no application to Title VII, whose language is not so clear. Although it is true that Title VII was the product of a bitterly contested compromise, ${ }^{74}$ nothing in the way the compromise provision was framed demands an absolute bar that would override the presumption that equitable modification is available. ${ }^{75}$

\section{Conclusion}

The treatment of Title VII's time limitations has been unduly confused. Part of this confusion stems from a failure to distinguish the purpose and scope of several rules of construction, such as those requiring inflexibility because the action is permitted only by waiver of sovereign immunity, because Congress expressly so limited the right, or because the statute of limitation is substantive. ${ }^{76}$ Still more disharmony stems from relying at all on the last of these rules when Supreme Court precedents and good sense show that it is spurious to do so. The ill-advised labeling of prerequisites to suit as "jurisdictional" has added to the confusion. When these false analyses are undermined, the foundation of absolute construction crumbles. Analogies to similar statutes whose time limitations may be modified equitably confirm that the provisions of Title VII demand similar construction.

Leo Katz

73 For a case so construing the Interstate Commerce Act, see A.J. Phillips Co. v. Grand Trunk W. Ry., 236 U.S. 662, 666-67 (1915); for cases construing the Federal Tort Claims Act, see Annot., 29 A.L.R. Fed. 482 (1976). Analysis of the latter statute is complicated by the fact that waiver of sovereign immunity is an independent reason why it has been construed as absolute. See text and notes at notes $\mathbf{4 2 - 4 5}$ supra. Nevertheless, some cases have remarked on its "forever barred" language. E.g., United States v. Wilkes-Barre Transit Corp., 143 F. Supp. 413, 415 (M.D. Pa. 1956). For a case analyzing the Securities Act of 1933, see Cook v. Avien, Inc., 537 F.2d 685, 691 (1st Cir. 1978). But see In re Home-Stake Prod. Co. Sec. Litigation, 76 F.R.D. 337, 344-45 (N.D. Okla. 1975). For a case discussing the Interstate Land Sales Full Disclosure Act, see Aldrich v. McCulloch Properties, Inc., 627 F.2d 1036, 1042-43 (10th Cir. 1980). But see Happy Inv. Group v. Lakeworld Properties, Inc., 396 F. Supp. 175, 188 (N.D. Cal. 1975).

74 See Mohasco Corp. v. Silver, 447 U.S. 807, 818-20, 826 (1980) (Stevens, J.). Cf. Moore v. Sunbeam Corp., 459 F.2d 811, 830 (7th Cir. 1972) (similar language by then-Judge Stevens).

${ }^{76}$ See note 13 supra.

7s An unusually precise delineation of some of these separate theories is outlined in Coles v. Penny, 531 F.2d 609, 613 (D.C. Cir. 1976). A particularly confused discussion of the theories is found in Jankwich, supra note 43 , at 151, 153-54. 